\title{
ON FARM EVALUATION OF THE EFFECT OF CRYSTALLIZER AND SOIL CONDITIONERS ON MAIZE GROWTH AND YIELD IN NIGER STATE
}

\author{
TSADO, J. H' ${ }^{1}$, OJO, M. A ${ }^{1}$. MOHAMMED, U.S ${ }^{1}$ AND GANA, D. T ${ }^{2}$. \\ 1 Department of Agricultural Economics and Extension Technology \\ Federal University of Technology, Minna, Niger State. \\ 2 National Cereal Research Institute, Baddegi, Bida, Niger State.
}

\begin{abstract}
This study was conducted to evaluate the effect of crystallizer and soil conditioners on maize growth and yield. Five locations were used. The farmers' practice of growing maize was compared side by side with technology of crystallizer and boost extra application. The effects of the applied treatments to maize increase the growth and yield parameter of maize. With the recommended practice field maize vigour on the average for all locations 3 and for farmers practice field on the average was 5 , implying normal vigour and weak vigour respectively. Maize height at maturity on the average for all locations with recommended practice was $262.2 \mathrm{~cm}$ and farmers practice field was $228.1 \mathrm{~cm}$. maize yield and it's component showed a positive respond to all the treatments in terms of percentage increase effect of application as follows height at maturity 13.1, days to 50\% tasselling 1.1 and grain yield ( $\mathrm{kg} / \mathrm{ha}$ ) 25.6, implying significant increase in height and yield of maize. It is recommended that both farmers and farm managers alike should adopt the application of crystallizers and soil conditioners using recommended practices to ensure proper growth and to obtain optimum yield from maize.
\end{abstract}

Key words: Crystallizer, Soil conditioners, Maize growth and Yield

\section{INTRODUCTION}

Maize is an important staple food for human and animal consumption. Also maize plant is grown in most part of the world for grains and silage production to meet the energy requirement of livestock (Tsama, 2005 and Idikut, et al 2009). Maize varieties are grown under a wide range of condition such as different soil types, soil fertility levels, moisture levels, temperature and cultural practices and all these variables encountered during the production affect the rate of growth and consequently the total output (yield) (Abdulahi et al, 2009). Farmers have long recognized the need to enhance soil properties, including its structure, nutritional and water retention capacities by using fertilizers and soil amendments. The term soil amendments include soil conditioners, fertilizers and crystallizers. Materials which make the soil more suitable for growth of plants are considered to be soil conditioners, (BCMAFF, 2004). Similarly Lawless et al (1984) argued that organic materials that have a carbon/nitrogen ratio greater than $30 \%$ should be considered as soil conditioners. Materials which supply certain essentials to plant to improve productivity are considered to be fertilizers, organic materials with a carbon/nitrogen ratio below $20 \%$ should be considered as fertilizers and these materials include crystallizers. Lawless (1984) also emphasized that humates and/or humic acid are good examples of non traditional soil conditioners, to drive his point home he conducted a research on the effect of humate on yield of irrigated corn and the result was as shown below. 
Table 1; Effect of humate on yield of irrigated corn.

\begin{tabular}{|c|c|c|c|c|}
\hline \multicolumn{5}{|c|}{ Grain yield (bu./ acre) } \\
\hline Treatment & 1978 & 1979 & 1980 & Average \\
\hline Control (no fertilizer) & 211 & 152 & 170 & 178 \\
\hline 50lbs. 18 - 46 0/acre & 213 & 149 & 177 & 180 \\
\hline 50lbs. $18-46-0 /$ acre +250 & & & & \\
\hline lbs.humate/acre ${ }^{2}$ & 208 & 162 & 172 & 181 \\
\hline $\begin{array}{l}50 \text { lbs.. } 18-460 / \text { acre }+ \\
500 \mathrm{lbs} . \text { humate/acre }\end{array}$ & 210 & 162 & 172 & 181 \\
\hline
\end{tabular}

According to Weaver et al (1974) fertilizer and soil conditioners must be spread evenly over the soil and most effective when incorporated into the crop root zoon, he also outlined some materials that can be used as soil amendments or conditioners which include the Lime (dolemite hydrated line), peat, Gypsum, Manure Sulphur, fertilizers (including Compost), and non agricultural waste (bio solids, compost, organic residues). Bauder (1976) and Elegba and Rente (1984) however warned that wastes can loose or change their value at any point in the nutrient management process, as such careful management is required to ensure that agricultural wastes which are applied to crop land do not produced nutrient rich run off which contaminates surface water supplies (lake, streams, marshes etc.) or leach through the soil and pollute ground water supplies.

Mohammed et al( 2009) also stresses that the beneficial effect of organic manure or bio fertilizers as well as micronutrient for increasing the productivity of sandy soils as a result of increasing the bio-available micronutrients (i.e. $\mathrm{Fe}, \mathrm{Mn}, \mathrm{Zn}$ and $\mathrm{Cu}$ and catasion exchange capacity, thereby enhancing the release of nutrients to plants. Li, et al (1999) also emphasized that such beneficial effects positively reflected on organic mater content as well as the dry weight and the plant content of $\mathrm{Fe}, \mathrm{Mn}, \mathrm{Zn}$ and $\mathrm{Cu}$ at the vegetative and elongation stages of maize growth. Demonstration plot are essential for the demonstration of new technology especially to small scale farmers scattered round the state, this physical demonstration was to show them the advantages of improved practices over their traditional practices, and to identify the key components of techniques from which small scale farmers could benefit from. Okigbo (1985) however reported that small scale farmers have poor resource base, are conservative and are not prepared to take risk in their farm operations, they have farm sizes that ranges from an average of 0.10 to 5 hectares per farm family. The demonstration plots were set out to passed across to the farmers extension messages which according to Ajayi (1987) includes: use of fertilizers, soil conditioners improved varieties of seeds simple farm implements (like power tillers) right plant spacing and the use of crop protection pesticides. Soil scientist and agronomist are often asked to provide recommendations on the use and effectiveness of new and non-traditional products. Many such products have not been scientifically evaluated; as such this type of study is essential so as to be able to give the best advice to maize growers by conducting small scale trails on farmers' field to serve as a medium for convincing them

The objectives include: comparison of the plant vigour on farmers practice fields and recommended practice fields; comparison of grain yield of maize on farmer practice fields and on recommended practice fields; comparison of grain yield of maize on farmers practice fields and on recommended practice fields; determine the percentage increase effect of the treatments on yield and yield parameter of maize. 


\section{MATERIALS AND METHODS}

Materials: The materials used include: Urea fertilizer containing mainly nitrogen, Crystallizer containing 21\% $\mathrm{P}_{2} 05 ; 5 \%$ Ma and Ca 5\%, Boost xtra containing $20 \%$ of Nitrogen; $20 \%$ of Phosphorus; $20 \%$ of Potassium; $5 \%$ of Magnesium oxide; $0.15 \%$ of iron; $0.075 \%$ of Manganese; 0.075 of Zinc; $0.0315 \%$ of Boron; $0.0012 \%$ of Copper and $.0012 \%$. Magnesium oxide

The Study Area: Niger state agricultural development projected was established in 1980 and the entire state was divided into 3 zones namely zone A, zone B, and Zone C. zone A were the research was carried out consist of seven local government areas. The major tribe of the area is Nupe, other settlers includes Hausa's, Fulani's. Igbo's and Yoruba's. The primary occupation of the people is farming and they grow mainly cereal crops like rice, maize G/corn and millet. The area is characterized by alternating seven months of dry season and five months of raining season. It has a main annual rain fall of about $1.100 \mathrm{~mm}-1.300 \mathrm{~mm}$, having an average rain fall of about $120 \mathrm{~mm}$. the climate and vegetative pattern coupled with sizeable expanse of arable fertile soil makes the area to be well suitable for cultivation of wide variety of crops (Kehinde, 1989). Niger state soils however according to FSED REPORT, (2007) have a range of very low phosphorous level as such supplementing the phosphorous will enhance it availability for crops use, similarly addition of Boost xtra micro nutrients will also enhance plant growth ,to this end application of both crystallizer and Boot xtra will increase maize grain yield and yield parameter.

Sampling Techniques: Five locations were purposely selected using multi-stage sampling techniques, this is because of the intensity of farming activities and the centralized nature of the locations, to enhance farmers' accessibility to the locations, and hence we have location A, B, C, D and E. The plots in each location were managed by farmers' groups and associations with their leaders as contact farmers. Both primary and secondary data were used for this study, primary data were collected using the research officers and contact farmers in each location.

Data Analysis Technique: This involved the use of simple descriptive statistics like frequency table, percentages and mean.

\section{RESULT AND DISCUSSION}

Table 2 shows maize vigour in farmers practice fields, using their own traditional methods and the recommended practice fields of the researcher. The result shows that maize plant in the researchers fields are more vigorous then those in farmers practice fields with an average scores of 5 and 3 implying weak and normal vigour respectively. Crystallizer application supplement the phosphorus in the soil there by enhancing plant vigour and boost xtra releases micronutrient thereby playing the same role.

Table 2: effect of Crystallizer and Boost xtra on maize plant vigour

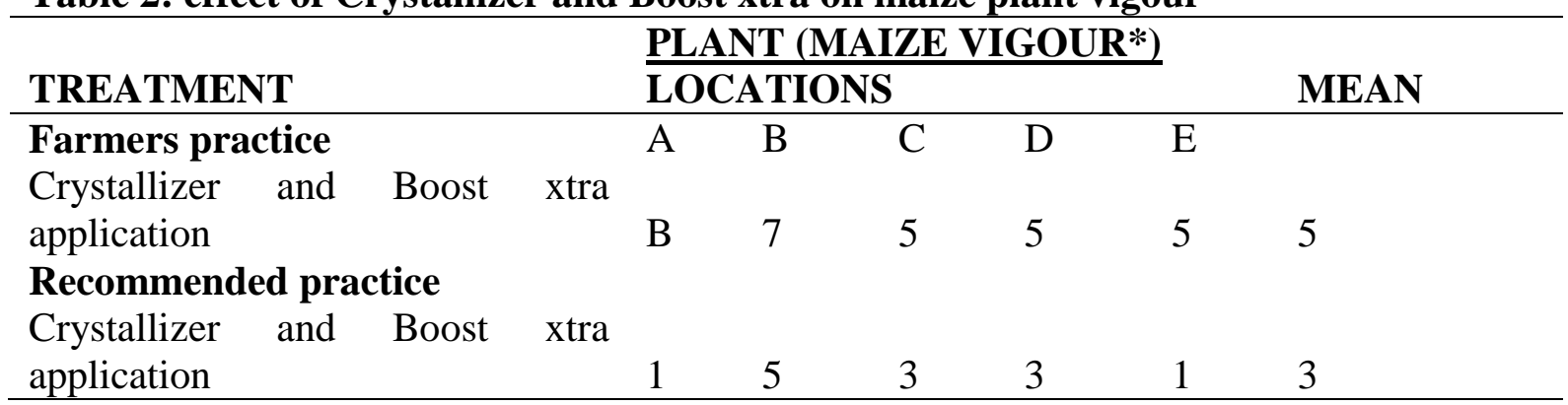

Source field survey 2008.

*Note: 1 = Extra Vigour; 2 = Vigorous; 3 = Normal Vigour; $4 \quad=$ Less than Normal

$5=$ Weak; 6 = Very Weak

Source: NCRI Badeggi, farming system $\backslash$ Extension Division report 2007. 
The result in table 3 reveals that maize plant developed more rapidly in recommended practice fields than in farmers practice fields with the application of crystallizer and boost xtra. The average height of $228.1 \mathrm{~cm}$ for farmers practice fieldts and $262.2 \mathrm{~cm}$ for recommended practices fields, indicating that recommended practices ensures rapid development and growth of maize plant than the farmers practices even when the same amount of input are used

Table 3: Effect of crystallizer, soil conditioners and Boost extra on maize plant growth.

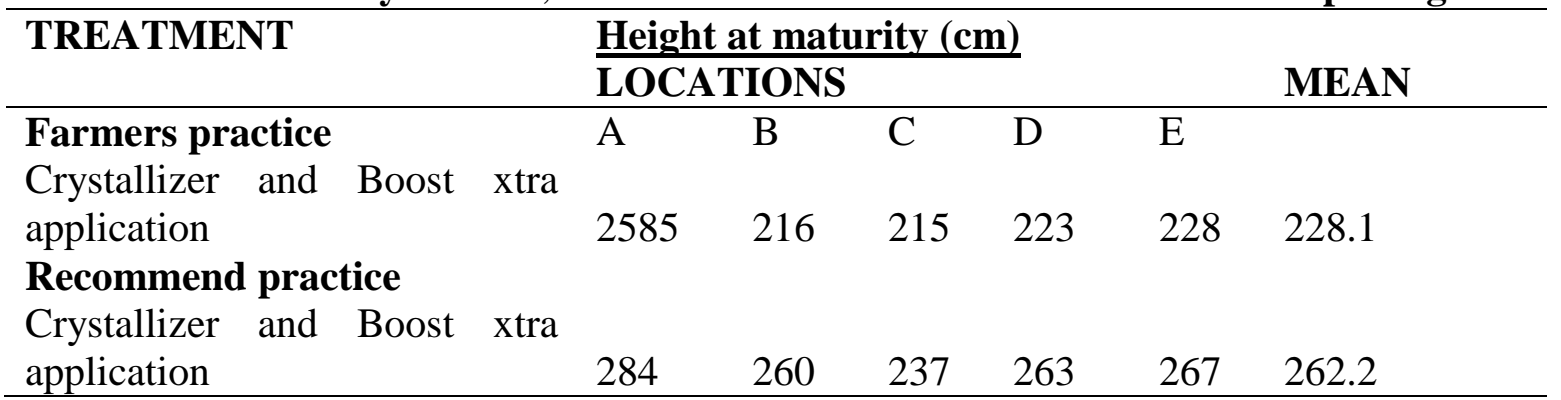

Source field survey, 2008.

Table 4: Effect of crystallizer and Boost xtra on maize grain yield

\begin{tabular}{|c|c|c|c|c|c|c|c|c|}
\hline TREAMENT & & & \multicolumn{5}{|c|}{ GRAIN YIELD (kg) } & MEAN \\
\hline Farmers practice & & & $\mathrm{A}$ & $\mathrm{B}$ & $\mathrm{C}$ & $\mathrm{D}$ & $\mathrm{E}$ & \\
\hline $\begin{array}{l}\text { Crystallizer and } \\
\text { application }\end{array}$ & Boost & xtra & 2.4 & 1.1 & 0.95 & 2.3 & 1.8 & 1.71 \\
\hline Recommended pr & tice & & & & & & & \\
\hline $\begin{array}{l}\text { Crystallizer and } \\
\text { application }\end{array}$ & Boost & xtra & 3.0 & 1.8 & 1.2 & 2.91 & 2.6 & 2.302 \\
\hline
\end{tabular}

Source field survey 2008

The average yield of farmers practice fields and recommended practice fields was $1.71 \mathrm{~kg}$ and $2.302 \mathrm{~kg}$ respectively. The yields of maize in recommended practice fields were overwhelmingly higher than those of farmers practice fields, this still point to the facts that farmer's traditional practices can not bring out the best even if improved inputs are used by them.

Table 5: Percentage increase effect of crystallizer and booth xtra on yield and yield parameters of maize in 2006 wet session.

\begin{tabular}{|c|c|c|c|}
\hline Treatment & Hight Maturity & Daily to $50 \%$ Tasselling & Grain yield kg/ha \\
\hline $\begin{array}{l}\text { Crystallizer + Boost } \\
\text { xtra Application }\end{array}$ & 13.1 & $\mathrm{~J}$ & 25.6 \\
\hline
\end{tabular}

As can be seen from table 5 application of crystallizer, Boost xtra and soil conditioners to increase yield and yield parameters of maize. Significant increase in height and yield of maize was recorded as a result of the application of crystallizer, Boost xtra and soil conditioners with the adoption of recommended practices.

\section{CONCLUSION}

The study evaluates the effect of crystallizer and soil conditioners on maize growth and yield. It is apparent from the results that the uses of crystallizer and soil conditioners improved soil 
fertility and consequently affect the growth and yield of maize plant. Maize plant vigour on farmer's practice field was extremely below average (5) while in recommended fieds it was above average (3). Heights at maturity of the recommended practices fieds are averagely higher than those of farmer's practice fields $262.2 \mathrm{~cm}$ and $228.1 \mathrm{~cm}$ respectively. Also the effect of the applied treatment on grain yield and quality of maize was higher for recommended practice fields than farmers practice fields at all locations, the overall being $1.71 \mathrm{~kg}$ for farmers practices fields and $2.302 \mathrm{~kg}$ for recommended practices, this implies that optimum yield could only be obtained by adopting recommended practices and finally increased in growth and grain of maize as can be seen from the study is an indication that the treatments had the ability to release plant promoting substances which might be stimulating plant growth as well as increasing the water and nutrient uptake by plant from the soil and consequently increasing the grain yield.

\section{RECOMMENDATIONS}

From this study, evaluating the effect of crystallizer and soil conditioners on maize growth and yield at 5 locations was adequate in identifying their effects. Based on the findings of the study it is recommended that farmers and farm managers should always adopt recommended practices so as to get the best (optimum) yield from application of crystallizers and soil conditioners, also farm managers and farmers alike should understand the requirement of their lands and crops and thoroughly assess the benefits and cost associated with various production practices, for achieving maximum economic yield from any plant (crop) depends largely up on using only those inputs which will with a reasonable certainty provide a return on that investment.

\section{REFERENCES}

Abdulla, M.S. Sallah, P.Y.K., and Safo Kantanka (2009): Maize yield stability analysis in full season low land maize in Ghana: International Journal of Agriculture \& Biology. 15608530/09-1-41-45.

Ajayi O., (1987): An exploratory Survey of the farming systems of Southern Kaduna State. Institute for Agricultural research. Ahmadu Bello University, Kaduna Nigeria.

Bakare S.O., Ukwungwu, M.N, Gana, D. T., Okonkwo and M. Mohammed (2007): on farm demonstration of the effect of crystallizer, soil conditioners and micronutrient on maize; farming systems and extension division report N.C.R.I Badeggi.

Bauder, J W. (1976): Soil conditioners. A problem or a solution? North Dakota agricultural experiment station. Reprint NO. 869. Farm Research. 33:21-34.

British Columbia, Ministry of Agriculture, food and Fisheries (BCMAFF)(2004): Fertilizer and Soil Conditioners. A Publication of Strengthening Farming Magazine, Right to Farm Order no 870,218-37.

Elegba, M.S. and R.J. Rennts (1984): Agrispon: microbial and elemental analysis and evaluation of it's effect on the growth of wheat, barley, Field beans and corn. Canadian journal of soil science. 64:21-629.

Farming System Extension Division Report ( Research Extension Inputs Linkage System Report) (2007) : 19 ${ }^{\text {th }}$ REFILS Workshop of the Middle Belt Zone, and the 2007 Research and Extension Review and Planning Meeting Held between 8-11 May, 2007, at NCRI Badeggi, Niger State.

Idikut L., Atalay, A.I, Kara, S.N and A. Kamalak (2009); Effect of hybrid on starch, protein and yield of maize grain. Journal of Animal and Veterinary Advances 8 (10) 19451947, 2009. ISSN. 1680-5593. Medwell journals, 2009 pp 1943 
Lawless, J.R,, Sunderman H.D., Lamm, F.L., and L.D. Roberson (1984):. Report of research result. Supplement 1. compendium of research reports on use of non-traditional materials for crop production. NCRI 103 committee. Iowe state press. Ames Iowe.

Li, W. and Sum, q. (1999) application of effective micronutrient in and production in china. Sixth international conference on kyusei. Nature farming Pretoria, Pretoria, South Arica, 23-31 October.

Mohammed, A .A. B., Yasser R.A.S, and A.M.M. Samir, (2009): Importance of micronutrient ,organic manure and bio fertilizer for improving maize yield and it's component grown in desert sandy soil: Research journal of agriculture and biological science, 5 (1) : 16-23-2009. Soil, water and environmental institute, agric. Research cantre, giza, Egypt.

Okigbo, B.N. (1985): Strategies in Research on improved farming system to facilitate adoption and management by Nigeria farmers; $2^{\text {nd }}$ ARMTI, Annual Lecture held in Ilorin. $31^{\text {st }}$ March, 1984

Tsamo, C .V .P. (2205): Moulds occurrence in maize (zea mays L.) grains and flours sold in the markets of Adamaoua provice in Cameroon National advance school for agroprocess industry (ENSA) Ngaoundere University, Ngaoundere, Cameroon.

Weaver, R.W.E.P., Duntgan, J.R. and A.E. Hutbold (1974): Effect of two soil activators on crop yield and activities of soil microorganism in the Southem united state Southerm cooperative series bulletin No 189. 